\title{
Caco-2 Cell Acquisition of Dietary Iron(III) Invokes a Nanoparticulate Endocytic Pathway
}

\author{
Dora I. A. Pereira ${ }^{1 \oplus}$, Bianca I. Mergler ${ }^{1 \oplus}$, Nuno Faria', Sylvaine F. A. Bruggraber ${ }^{1}$, Mohamad F. Aslam¹, \\ Lynsey K. Poots ${ }^{1}$, Laura Prassmayer ${ }^{1}$, Bo Lönnerdal², Andy P. Brown ${ }^{3}$, Jonathan J. Powelli
}

1 Medical Research Council Human Nutrition Research (MRC HNR), Elsie Widdowson Laboratory, Cambridge, United Kingdom, 2 Department of Nutrition, University of California Davis, Davis, California, United States of America, 3 Institute for Materials Research, School of Process, Environmental and Materials Engineering, University of Leeds, Leeds, United Kingdom

\begin{abstract}
Dietary non-heme iron contains ferrous $[\mathrm{Fe}(\mathrm{II})]$ and ferric $[\mathrm{Fe}(\mathrm{III})]$ iron fractions and the latter should hydrolyze, forming $\mathrm{Fe}$ (III) oxo-hydroxide particles, on passing from the acidic stomach to less acidic duodenum. Using conditions to mimic the in vivo hydrolytic environment we confirmed the formation of nanodisperse fine ferrihydritelike particles. Synthetic analogues of these $(\sim 10 \mathrm{~nm}$ hydrodynamic diameter) were readily adherent to the cell membrane of differentiated Caco-2 cells and internalization was visualized using transmission electron microscopy. Moreover, Caco-2 exposure to these nanoparticles led to ferritin formation (i.e., iron utilization) by the cells, which, unlike for soluble forms of iron, was reduced $(p=0.02)$ by inhibition of clathrin-mediated endocytosis. Simulated lysosomal digestion indicated that the nanoparticles are readily dissolved under mildly acidic conditions with the lysosomal ligand, citrate. This was confirmed in cell culture as monensin inhibited Caco-2 utilization of iron from this source in a dose dependent fashion $(p<0.05)$ whilet soluble iron was again unaffected. Our findings reveal the possibility of an endocytic pathway for acquisition of dietary Fe(III) by the small intestinal epithelium, which would complement the established DMT-1 pathway for soluble Fe(II).
\end{abstract}

Citation: Pereira DIA, Mergler BI, Faria N, Bruggraber SFA, Aslam MF, et al. (2013) Caco-2 Cell Acquisition of Dietary Iron(III) Invokes a Nanoparticulate Endocytic Pathway. PLoS ONE 8(11): e81250. doi:10.1371/journal.pone.0081250

Editor: Neil A. Hotchin, University of Birmingham, United Kingdom

Received July 16, 2013; Accepted October 10, 2013; Published November 21, 2013

Copyright: $\odot 2013$ Pereira et al. This is an open-access article distributed under the terms of the Creative Commons Attribution License, which permits unrestricted use, distribution, and reproduction in any medium, provided the original author and source are credited.

Funding: This work was funded by the UK Medical Research Council (MRC) (U105960399), MRC Technology Development Gap Fund (DGF), Action Medical Research (SP4528) and WellChild. The funders had no role in study design, data collection and analysis, decision to publish, or preparation of the manuscript.

Competing interests: The authors declare no conflict of interest but D.I.A.P., N.F., S.F.A.B. and J.J.P. wish to note that they are inventors on a patent detailing novel Fe(III) poly oxo-hydroxide structures that may have potential as dietary supplements [Powell, J., S. Bruggraber, et al. (2008). Ligand modified poly oxo-hydroxy metal ion materials, their uses and processes for their preparation. W. I. P. Organization, U.K. WO/2008/096130]. This patent does not alter adherence to all PLOS ONE policies on sharing data or materials.

*E-mail: jonathan.powell@mrc-hnr.cam.ac.uk

๑ These authors contributed equally to this work.

\section{Introduction}

Dietary non-heme iron (Fe) contains ferrous [Fe(II)] and ferric [Fe(III)] fractions in a number of chemical forms: for example $\mathrm{Fe}$ in ferritin and in Fe-sulphur cluster proteins [1-3]. Redox changes to dietary $\mathrm{Fe}$ between the points of ingestion and cellular uptake from the intestinal lumen are complex and may favour oxidation to $\mathrm{Fe}(\mathrm{III})$ due to intestinal $\mathrm{pH}$ and endogenous ligands, or reduction to $\mathrm{Fe}(\mathrm{II})$ due to the presence of ascorbate and low luminal oxygen levels [4,5]. Overall, however, both $\mathrm{Fe}(\mathrm{II})$ and $\mathrm{Fe}$ (III) appear to reach the intestinal epithelial surface to some extent $[4,6-8]$. Fe(II) is transported by the divalent metal transporter-1 (DMT-1) and $\mathrm{Fe}(\mathrm{III})$ is proposed to undergo enzymatic reduction to $\mathrm{Fe}(\mathrm{II})$, perhaps by duodenal cytochrome B (DcytB), prior to transport by DMT-1 [9-13]. Chemically, however, there is an uncomfortable paradox with respect to this latter pathway. $\mathrm{Fe}$ (III) is remarkably insoluble at duodenal $\mathrm{pH}$, immediately precipitating out of solution as $\mathrm{Fe}$ (III) poly oxo-hydroxide:

$\left[\log \mathrm{K}_{\mathrm{eq}} \mathrm{Fe}^{3+}+3 \mathrm{H}_{2} \mathrm{O} \leftrightarrow \mathrm{Fe}(\mathrm{OH})_{3}+3 \mathrm{H}^{+}=-11.7\right.$ [14]].

To obviate iron precipitation several authors have suggested the presence of endogenous Fe binding agents (i.e. proteins, organic acids etc.) in gastrointestinal secretions that retain $\mathrm{Fe}(\mathrm{III})$ in a soluble form. The aluminium ion $(\mathrm{Al}(\mathrm{III}))$ can be viewed as a kinetically less labile, non-paramagnetic metal ion (M) 'probe' for Fe(III). Work on the chemical speciation of $\mathrm{Al}(\mathrm{III})$ in the intestinal lumen did not identify any endogenous ligands that could prevent its precipitation as an oxo-hydroxide at perineutral $\mathrm{pH}$ [15]. Instead, Powell et al. proposed that a range of endogenous, low molecular weight ligands could slow the rate of hydrolysis to allow M(III) binding to gastrointestinal mucins [15]. Indeed, luminal Fe binding to gastrointestinal mucins has 
been identified by a number of authors $[8,16,17]$ and so effective is this binding that gastric mucin has been previously referred to as 'gastroferrin': the endogenous gastro(intestinal) molecule that can keep dietary Fe(III) in 'solution' [18-24]. Rudzki et al. detailed the nature of the binding between $\mathrm{Fe}(\mathrm{III})$ and the Fe-binding glycoprotein of gastric juice (mucin) and showed that at $\mathrm{pH}$ values of the proximal bowel (typical $\mathrm{pH}$ range 5.8-6.7 [25]), $\mathrm{Fe}(\mathrm{III})$ is not quite kept in 'solution' [26].Instead, it appears that Fe(III) commences hydrolysis but further growth and agglomeration of the $\mathrm{Fe}(\mathrm{III})$ poly oxohydroxide nanoparticles are prevented by mucin binding [26]. They visualized the nanoparticles formed in the Fe-glycoprotein complex, noting that they were $\sim 10-20 \mathrm{~nm}$ in diameter and appeared to be amorphous aggregates. The $\mathrm{Fe}(\mathrm{III})$ oxohydroxide phase expected to first precipitate from an $\mathrm{Fe}(\mathrm{III})-$ bearing solution at proximal small bowel $\mathrm{pH}$ is ferrihydrite [27]. This is a cross-linked polymeric (i.e. poorly (nano)crystalline) phase with primary platelets of $2-5 \mathrm{~nm}$ in size depending on the degree of crystallinity and is prone to agglomeration and aggregation [28]. Rudzki et al. produced a synthetic version, referring to this phase as colloidal Fe and, importantly, showed that direct instillation of this ferrihydrite-mucin solution into the duodenum of rats, led to $\mathrm{Fe}$ absorption nearly equivalent to that of the gold standard, Fe(II) ascorbate [26].

How nanoparticulate $\mathrm{Fe}$ (III) poly oxo-hydroxide, which is insoluble at duodenal $\mathrm{pH}$, would be acquired by enterocytes and processed for absorption and utilization is not clear. Current understanding of dietary $\mathrm{Fe}(\mathrm{III})$ absorption suggests synergistic association between an intestinal ferrireductase (e.g. DcytB) and the apical Fe(II) transporter ( DMT-1) such that the enzyme reduces $\mathrm{Fe}(\mathrm{III})$ allowing its transport and absorption. However, our current in vivo studies reasonably preclude the requirement for reduction and dissolution of $\mathrm{Fe}(\mathrm{III})$ poly oxo-hydroxide prior to uptake by the enterocyte (Pereira, Latunde-Dada and Powell; unpublished observations). To investigate the above paradox in more detail we first built on the model of Rudzki et al. [26,29] using mucin plus typical low molecular weight ligands of the gastrointestinal lumen to better mimic in vivo $\mathrm{Fe}(\mathrm{III})$ hydrolysis. We confirmed the formation of a fine ferrihydrite-like phase in 'luminally hydrolysed' dietary $\mathrm{Fe}$ (III) and then we probed cellular uptake and utilization of synthetic ligand-modified ferrihydrite, as an analogue for this nanoparticulate phase, demonstrating the requirement of endocytic uptake mechanisms.

\section{Materials and Methods}

\section{Synthesis of iron materials}

Soluble Fe(II) material was prepared by mixing an acidified stock solution of $\mathrm{Fe}(\mathrm{II})$ sulphate heptahydrate $(40 \mathrm{mM})$ with a stock solution of ascorbic acid $(0.5 \mathrm{M})$ to achieve a molar ratio of 1:100 (Fe:ascorbic acid). Soluble $\mathrm{Fe}(\mathrm{III})$ maltol chelate (Fe(III) maltol) was produced by mixing a stock solution of $\mathrm{Fe}$ (III) chloride (8 $\mathrm{mM}$ ) with a maltol (3-hydroxy-2-methyl-4Hpyran-4-one) solution $(40 \mathrm{mM})$ to achieve a molar ratio of Fe:maltol of 1:5. Soluble Fe(III) nitrilotriacetate chelate (Fe(III) NTA) was produced by mixing a solution of $\mathrm{Fe}(\mathrm{III})$ chloride (8 $\mathrm{mM}$ ) with a NTA solution to achieve a molar ratio of Fe:NTA of
1:5. The $\mathrm{pH}$ of the above mixtures was adjusted to 7.4 with $\mathrm{NaOH}$ prior to use. Ligand-modified (LM) Fe(III) poly oxohydroxide material was produced following the protocol described by Powell et al. [30]. Briefly, an acidic concentrated stock solution of $\mathrm{Fe}(\mathrm{III})$ chloride $(40 \mathrm{mM})$ was added to a solution containing tartaric acid and adipic acid or, in the case of un-modified $\mathrm{Fe}(\mathrm{III})$ oxo-hydroxide, to $0.9 \%(\mathrm{w} / \mathrm{v})$ of electrolyte (potassium chloride). The initial $\mathrm{pH}$ of the mixture was always below 2.0 and the iron was fully solubilized. The $\mathrm{pH}$ was then slowly increased by drop-wise addition of a concentrated solution of $\mathrm{NaOH}$ with constant agitation until the desired final $\mathrm{pH}$ (ca. 7.4 for LM Fe(III) poly oxo-hydroxide and 7.4-8.2 for un-modified $\mathrm{Fe}$ (III) oxo-hydroxide) were attained. In the case of LM Fe(III) poly oxo-hydroxide the ratio of Fe:tartaric acid:adipic acid in the final suspension was 2:1:1.

\section{Chemical characterisation}

Detailed methods of the below are provided in the Supplementary Methods S1. Fe(III) structures were characterised by transmission electron microscopy (TEM) after hydrolysis of $\mathrm{Fe}(\mathrm{III})$ in simulated digestion medium. The solubility of LM Fe(III) poly oxo-hydroxide and un-modified $\mathrm{Fe}$ (III) poly oxo-hydroxide (i.e. standard synthetic ferrihydrite) was determined at $\mathrm{pH} 5.0 \pm 0.1$ in a $10 \mathrm{mM}$ citric acid, $0.15 \mathrm{M}$ $\mathrm{NaCl}$ solution. The Fe material was added to the assay solution at an Fe concentration of ca. $1 \mathrm{mM}$ and incubated for $360 \mathrm{~min}$ at room temperature. Soluble iron was determined following ultrafiltration (3,000 Da MWCO). The hydrodynamic particle size of the nanoparticulate LM Fe(III) poly oxo-hydroxide material was determined by Dynamic Light Scattering (DLS) and the non-aquated primary particle size by Transmission Electron Microscopy (TEM).

\section{Cellular uptake studies}

To avoid aggregation/agglomeration of the nanoparticulate iron, the medium for cellular uptake consisted of a balanced salt solution (BSS) containing $130 \mathrm{mM} \mathrm{NaCl}, 10 \mathrm{mM} \mathrm{KCl}, 1 \mathrm{mM}$ $\mathrm{MgSO}_{4}, 5 \mathrm{mM}$ Glucose and $1 \mathrm{mM} \mathrm{CaCl}_{2}$ in $10 \mathrm{mM}$ PIPES buffer $(\mathrm{pH}$ 7.4). Immediately before the cellular uptake experiments, fresh solutions of the Fe materials were prepared in BSS at an Fe concentration of $200 \mu \mathrm{M}$ and the partition of the $\mathrm{Fe}$ into the soluble, nanoparticulate and microparticulate fractions was assessed to assure that most of the Fe (i.e. $>90 \%$ ) was present in the nanoparticulate fraction and had not agglomerated/aggregated. DLS measurements were also taken of the nanoparticulate fraction to assure a mono-disperse distribution of the intended size (i.e. $\sim 10 \mathrm{~nm}$ ). Detailed methodology is shown in Methods S1.

\section{Iron uptake in undifferentiated Caco-2 cells}

Human adenocarcinoma (Caco-2) cells were obtained from ATCC (LGC standards, Middlesex, United Kingdom). Cells were seeded at $1.13 \times 10^{6}$ cells $/ \mathrm{mL}$ onto 6 -well cell culture plates. Plates were centrifuged at $680 \mathrm{xg}$ for $5 \mathrm{~min}$ to remove the growth medium. The different $\mathrm{Fe}$ preparations in uptake medium were carefully added to the cells and incubated for $1 \mathrm{~h}$ at $37^{\circ} \mathrm{C}$. Uptake medium with no supplemented Fe was also incubated with cells as a control. Each condition was tested in 
triplicate wells for each experiment. After the $\mathrm{Fe}$ incubation period, the uptake medium was removed by centrifugation and aspiration, and the cells were washed with phosphate buffered saline (PBS)-EDTA (2 $\mathrm{mM}$ ) to remove any loosely bound Fe. The cells were then resuspended in fresh MEM (with no supplemental $\mathrm{Fe}$ ) and returned to the incubator for an additional $23 \mathrm{~h}$ to allow for ferritin-protein formation to plateau [31]. At the end of the incubation period, the cells were washed with Dulbecco's Phosphate-Buffered Saline (DPBS; PAA Laboratories) and lysed with Mammalian Protein Extraction Reagent (MPER ${ }^{\circledR}$, Thermo Fisher Scientific, Cramlington, UK). After lysis, cell debris was removed by centrifugation (5 min, $16,000 \mathrm{xg}$ ) and the supernatant used for analysis.

\section{Iron uptake in differentiated Caco-2 cells}

Cells (Caco-2 ATCC as above) were seeded at ca. $1.8 \times 10^{5}$ cells $/ \mathrm{mL}$ onto 6 -well cell culture plates. The Caco- 2 cells were maintained under the culture conditions described in Methods $\mathrm{S} 1$ and used for the Fe uptake experiments at 11 or 12 days post-seeding. Cell differentiation and formation of a cell monolayer were confirmed for this timepoint as described in Methods S1. Approximately $16 \mathrm{~h}$ prior to the experiments the growth medium was replaced by non-supplemented MEM, i.e. without FBS or antibiotics, and cells were returned to the incubator. This was carried out to 'starve' cells of Fe prior to the experiments and did not induce any changes in the cell monolayer integrity as confirmed by TEER measurements. The Caco-2 cell monolayer was then washed once with pre-warmed DPBS and incubated with the different Fe materials or control uptake medium for $1 \mathrm{~h}$ at $37^{\circ} \mathrm{C}$. For each experiment every condition was investigated in triplicate wells. Following the $\mathrm{Fe}$ incubation period the uptake medium was removed, the cell monolayer was washed three times with PBS-EDTA (2 mM) to remove any Fe loosely adherent to the cell membrane and fresh non-supplemented MEM was added. The cells were then returned to the incubator for an additional $23 \mathrm{~h}$ to allow for ferritin-protein formation [31]. At the end of the incubation period, the cells were washed and lysed as before. The cell lysate supernatant was used for analysis.

The Caco-2 cells requirement of energy for Fe uptake from $\mathrm{Fe}$ (III) maltol or the nanoparticulate LM Fe(III) poly oxohydroxide was investigated by low temperature incubation. The cells were kept on ice for 10 min prior to the experiment and during the $1 \mathrm{~h}$ incubation period with the two $\mathrm{Fe}$ materials suspended in uptake medium. The cells were then washed 3 times with ice-cold PBS-EDTA (2 $\mathrm{mM})$ and fresh nonsupplemented MEM was added and the cells incubated for the remaining $23 \mathrm{~h}$ at $37^{\circ} \mathrm{C}$ and treated as above.

To study the effect of endocytosis-related-pathway-inhibitors on Fe uptake from the different materials, Caco- 2 cells were co-incubated for $1 \mathrm{~h}$ at $37^{\circ} \mathrm{C}$ with the Fe materials in BSS supplemented with the following inhibitors (each inhibitor tested in triplicate wells): chlorpromazine $(100 \mu \mathrm{M})$, filipin $(5 \mathrm{mg} / \mathrm{L})$, methyl- $\beta$-cyclodextrin (5 mM). Additionally, cells were incubated with $\mathrm{Fe}$ in $\mathrm{K}^{+}$-free BSS consisting of $130 \mathrm{mM} \mathrm{NaCl}, 1$ $\mathrm{mM} \mathrm{MgSO}_{4}, 5 \mathrm{mM}$ glucose and $1 \mathrm{mM} \mathrm{CaCl}_{2}$ in $10 \mathrm{mM}$ PIPES buffer ( $\mathrm{pH}$ 7.4). For this experimental condition cells were preincubated for 5 min with a 1:1 mixture of Dulbecco's Modified
Eagle Medium (DMEM):water prior to incubation in $\mathrm{K}^{+}$-free medium. For the cellular lysosomal dissolution experiments, cells were co-incubated for $1 \mathrm{~h}$ at $37^{\circ} \mathrm{C}$ with the Fe materials in BSS supplemented with monensin $(5-30 \mu \mathrm{M})$. As before ferritinformation was assessed at $23 \mathrm{~h}$ following the removal of the inhibitors and Fe materials. Controls were performed for each inhibitor by incubating the cells with uptake medium (BSS) supplemented with the inhibitor but not containing Fe.

Chlorpromazine $[32,33]$ and $\mathrm{K}^{+}$free BSS $[33,34]$ were used to inhibit clathrin-mediated uptake. Filipin [35] and methyl- $\beta$ cyclodextrin $[34,36]$ were used to inhibit caveolin-mediated uptake. Monensin was used to inhibit acidification of endosomes/lysosomes [37-39].

\section{Analysis}

Cell lysate supernatants were analysed for cellular ferritinprotein content using the commercial enzyme-linked immunosorbent assay kit "Spectro Ferritin" (ATI Atlas, Chichester, UK). The uptake data were normalized to total cell protein content determined with the non-interfering protein assay $^{T M}$ (NIPA ${ }^{T M}$, Calbiochem/Merck, Nottingham, UK). TEER measurements were carried out to determine if the chemical inhibitors used in the uptake studies had a negative impact on the integrity of the cell monolayer (an early indication of toxicity) as detailed in Methods S1. Electron microscopy was used to visualize nanoparticulate Fe uptake by the Caco-2 cells as detailed in Methods S1.

\section{Statistical analysis}

All statistical analysis was performed using GraphPad Prism version 6 for Windows (GraphPad Software, San Diego, California, USA). Unless stated otherwise, results are presented as means with standard deviations (s.d.). The unpaired t-test was used to statistically compare ferritin-protein formation for the different Fe compounds in differentiated and undifferentiated cells and ferritin-protein formation with and without chemical inhibitors of endocytosis-related pathways (level of significance set to $p<0.05$ ). The repeated measures 2way ANOVA with Sidak correction for multiple comparisons was used to statistically compare TEER at different time points. Regular 2-way ANOVA (no matching) was used to statistically compare ferritin formation for different monensin doses between the nano $\mathrm{Fe}$ and the soluble $\mathrm{Fe}$ materials. Ferritinprotein concentration in the presence of monensin was fitted with a non-linear dose-response inhibition curve (i.e. $\log _{10}$ (inhibitor) versus response).

\section{Results and Discussion}

\section{Formation and cellular uptake of ligand-modified Fe(III) poly oxo-hydroxide nanoparticles}

First, as a mimetic of gastrointestinal hydrolysis conditions, $\mathrm{Fe}$ (III) chloride was dissolved at $\mathrm{pH} 1.2$ in a solution of relevant, low molecular weight ligands and gastric porcine mucin and then adjusted to $\mathrm{pH}$ 6.5-7.1 using sodium bicarbonate (final $\mathrm{Fe}$ concentration $1 \mathrm{mM}$ ) (detailed methodology is available in Methods S1). A drop of the 
resultant 'solution' (colloidal suspension) was placed on a thin amorphous carbon film for TEM and imaged. Agglomerates of fine $(\sim 5 \mathrm{~nm})$ poorly crystalline particles in an amorphous gel were noted (Figure 1A). Whole area energy dispersive $\mathrm{X}$-ray spectroscopy (EDX) showed these to be Fe-containing (Figure 1B), and electron diffraction (not shown) indicated a mixture of two phases - ferrihydrite-like (two broad diffraction rings characteristic of 2-line ferrihydrite [40]) and a second phase which was not uniquely identified (two broad diffraction rings at 0.20 and $0.13 \mathrm{~nm}$ ). Under prolonged exposure to the electron beam the particles agglomerated further, developed in crystallinity and the diffraction pattern became dominated by this second phase: it was still not possible to confirm the identity of this alteration product but an $\mathrm{Fe}$ phosphate hydroxide provides the closest match to the observed lattice spacings (International Centre for Diffraction Data powder diffraction file 00-047-0413). Irradiation damage to poorly crystalline fine particles such as ferrihydrite [41] is well recognized, especially in the absence of supporting resin or tissue structure, so we considered this second phase to be artifactual. Hence the larger particles $(10-20 \mathrm{~nm})$ observed in the earlier work of Rudzki et al. [26] are, likely, an artifact of beam damage but the smaller particles are not. Moreover, the hydrolysis of the $\mathrm{Fe}(\mathrm{III})$ and the formation of these fine, disperse, ferrihydrite-like particles was not prevented by the presence of typical gastrointestinal low-molecular weight ligands. As a simplified and practical analogue to the above ferrihydrite-like particles we have developed ligand-modified (LM) Fe(III) poly oxo-hydroxides of similar size and structure [30]. This ligand-modified analogue remains well-dispersed upon aqueous suspension in the uptake medium used for cellular experiments (balanced salt solution: BSS) taking on an average hydrodynamic particle diameter of $10 \mathrm{~nm}$ (Figure 1C).

Here, ferritin-protein formation of epithelial cell cultures, as a measure of cellular iron utilisation, was assessed following a 24 $\mathrm{h}$ total incubation period that involved $1 \mathrm{~h}$ Fe exposure of cells in BSS followed by washing, change of medium, and a $23 \mathrm{~h}$ incubation in non-supplemented minimum essential medium (MEM) (i.e. with very low Fe content). We used soluble Fe, either as $\mathrm{Fe}$ (III) maltol [42] or $\mathrm{Fe}$ (II) sulphate-ascorbate as positive controls [31]. Initially, we used both differentiated and undifferentiated cells and iron utilization varied greatly for the LM Fe(III) poly oxo-hydroxide structures (undifferentiated > differentiated; $p=0.0003$ ) but not at all for the soluble $\mathrm{Fe}(\mathrm{III})$ (Figure 2A). Alkaline phosphatase levels were used as a marker for Caco-2 cell differentiation and the integrity of the cell monolayer was assured prior to the experiments (see Figure S1). The solid phase distribution, i.e. the partition of the $\mathrm{Fe}$ in the soluble, nanoparticulate (aquated) or microparticulate (agglomerated) fractions, largely confirmed the nanoparticulate nature of the LM Fe(III) poly oxo-hydroxide and the solubility of the $\mathrm{Fe}(\mathrm{III})$ maltol and $\mathrm{Fe}(\mathrm{II})$ sulphate-ascorbate (Figure 2B). Cellular uptake and utilization of the LM Fe(III) poly oxohydroxide required nano dispersion because purposeful agglomeration to microparticles (first hour in MEM, rather than in BSS, leading to $97 \pm 2 \%$ microparticulate iron at $30 \mathrm{~min}$ ) prevented iron utilization (Figure $2 \mathrm{C}$ ). We confirmed that BSS did not affect monolayer integrity for the duration of the exposure (Figure 2D) although Fe(II) sulphate-ascorbate did [31], so further cellular work used $\mathrm{Fe}(\mathrm{III})$ maltol as the soluble control.

Hence, the uptake and utilization of LM Fe(III) poly oxohydroxide required its dispersion in nanoparticulate form (Figure 2C) and the mechanism of acquisition appeared different to that of soluble Fe (Figure 2a). Next we investigated energy requirements for $\mathrm{Fe}$ uptake by comparing data at $37^{\circ} \mathrm{C}$ with those at low temperature (i.e. on ice). Fe utilization from $\mathrm{Fe}(\mathrm{III})$ maltol at low temperature was decreased by $95 \%(95 \pm$ 1; $n=3$ ) as expected, but from nanoparticulate LM Fe(III) poly oxo-hydroxide the reduction was only ca. $20 \%(19 \pm 13 ; n=3)$ (Figure S2). Apparent low temperature uptake of nanoparticles has been observed before $[43,44]$ and is attributed to particle adhesion to the cell membrane. Adherent particles, that withstand washing, may be subsequently taken up by cells (and in this case utilized to form ferritin-protein, indicating that cells remained healthy) upon re-incubation in fresh medium at $37^{\circ} \mathrm{C}$. Electron microscopy indicated cell surface adhesion of the nanoparticles and also showed that, generally, the cell membrane tended to induce loose agglomeration or aggregation of the particles into clusters up to $200 \mathrm{~nm}$ in diameter (Figure 3A). Thus we considered that Fe from the LM $\mathrm{Fe}$ (III) poly oxo-hydroxide nanoparticles was utilized following acquisition by endocytic uptake, as this is superior in undifferentiated versus differentiated Caco-2 cells [45], and cell surface adhesion is a requirement prior to uptake. Indeed further electron microscopy work revealed evidence of cell surface invagination (Figure $3 \mathrm{~B}$ ) with respect to the surface clusters of LM Fe(III) poly oxo-hydroxide and showed loose agglomerates of $\leq 200 \mathrm{~nm}$ in diameter within vesicles that we suggest are endosomes or lysosomes (Figure 3C, D). TEM images were also collected for control Caco-2 cells: i.e. cells incubated with non-supplemented BSS and cells incubated with BSS supplemented with the soluble Fe(III) maltol chelate and no discernible particulate Fe was observed (Figure S3). To determine whether nanoparticulate uptake contributed to cellular Fe utilization of the LM Fe(III) poly oxo-hydroxide we used an inhibitor of clathrin-mediated endocytosis, namely chlorpromazine, at a dose of $100 \mu \mathrm{M}$ consistent with previous studies [32,33]. We confirmed that this significantly reduced $(p=0.02)$ ferritin-protein formation in the cells exposed to LM $\mathrm{Fe}(\mathrm{III})$ poly oxo-hydroxide (Figure $3 \mathrm{E}$ ), without significantly affecting monolayer integrity (Figure $3 F$ ), whilst no difference was observed for soluble iron uptake (Figure 3E, F). Further endocytic-inhibition studies with $\mathrm{K}^{+}$depletion, filipin and methyl$\beta$-cyclodextrin suggested the same picture: namely that $\mathrm{Fe}$ utilization appeared reduced albeit so only for LM Fe(III) poly oxo-hydroxide exposure and not for soluble Fe (Figure 3D). Interestingly, filipin and methyl- $\beta$-cyclodextrin inhibit caveolaerelated rather than clathrin-mediated endocytosis so, consistent with previous nanoparticulate uptake work, there either appears to be a degree of redundancy/overlap between the uptake pathways [43] or precise uptake may be related to the size range of the nanoparticulate clusters formed on the cell membrane [46-49]. All cell monolayers appeared healthy under the microscope, and also without significant changes in TEER measurements, under the assay conditions used with $\mathrm{K}$ 


\section{Figure 1. Characterisation of hydrolysed Fe(III) with simulated digestion and of aquated LM Fe(III) poly oxo-hydroxide.}
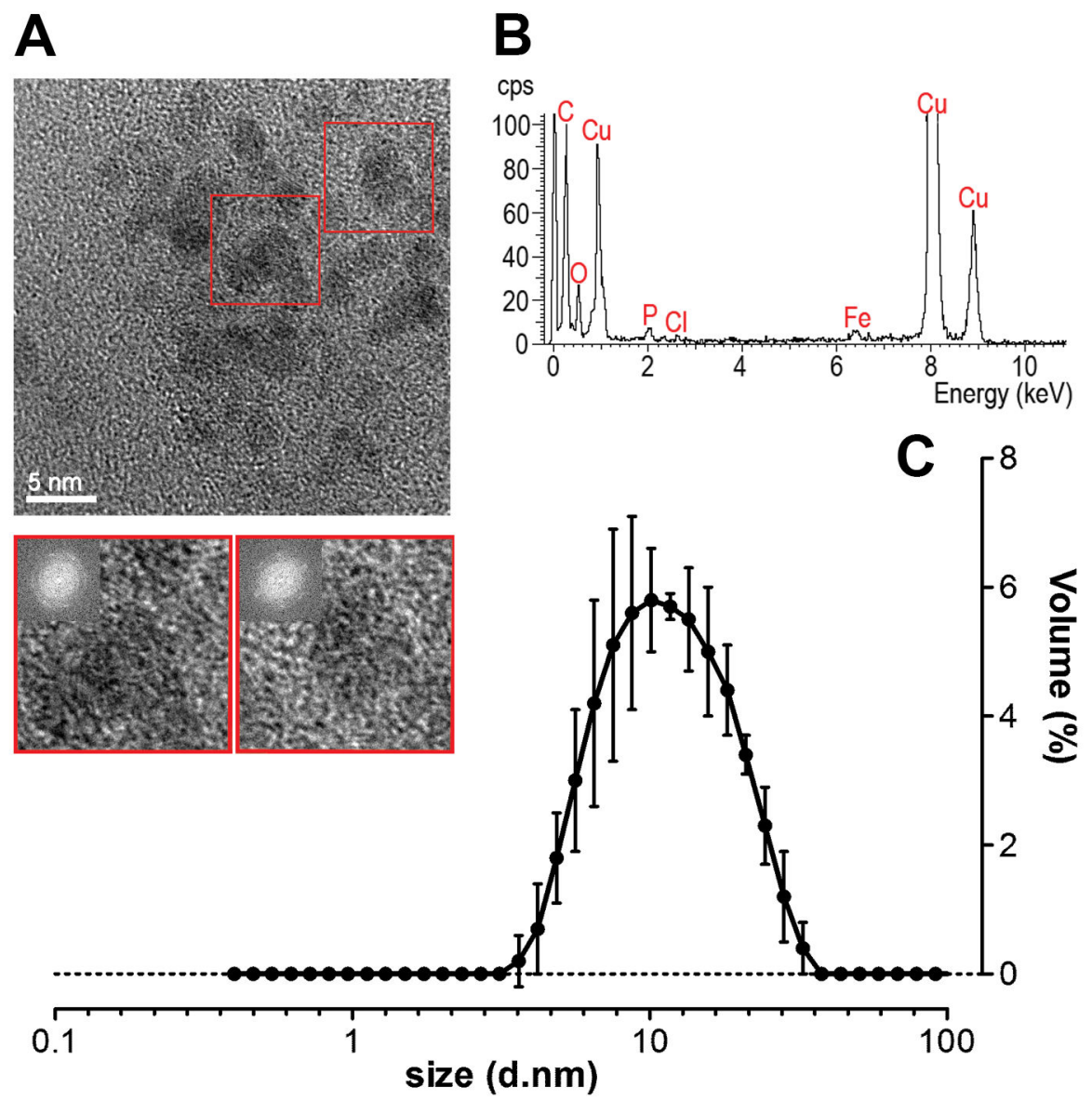

Figure 1. Characterisation of hydrolysed Fe(III) with simulated digestion and of aquated LM Fe(III) poly oxo-hydroxide. A, Transmission Electron Microscopy (TEM) images collected from a drop of suspension after simulated digestion of $1 \mathrm{mM}$ Fe(III) chloride in the presence of $2 \mathrm{~g} / \mathrm{L}$ mucin and low molecular weight ligands. The boxed regions are shown magnified below and highlight the presence of fine, poorly crystalline nanoparticles dispersed in an amorphous gel. Crystallinity is indicated by the spots in the inset diffractograms (fast Fourier transforms) in the boxed regions and lattice spacings are discussed in the main text. Scale bar represents $5 \mathrm{~nm}$. B, Whole area EDX analysis of a particle agglomerate similar to those in 'A' shows elemental compositions (the specimen support film and grid produce the background $\mathrm{C}$ and $\mathrm{Cu}$ signals respectively). C, Hydrodynamic size distribution of nanoparticulate $500 \mu \mathrm{M}$ LM Fe(III) poly oxo-hydroxide in balanced salt solution (BSS) measured by Dynamic Light Scattering (DLS). Values are expressed as mean diameter \pm s.d. (3 independent measurements) on a $\log _{10}$ scale. .

doi: 10.1371/journal.pone.0081250.g001

${ }^{+}$-free BSS and methyl- $\beta$-cyclodextrin (Figure 3F), although no TEER assessment was made with filipin.

\section{Lysosomal dissolution of ligand-modified Fe(III) poly oxo-hydroxide nanoparticles enables cellular utilization of iron}

Overall, direct endocytosis of LM Fe(III) poly oxo-hydroxide nanoparticles by differentiated Caco-2 cells appears, chiefly, to explain uptake of Fe under these conditions. However, this Fe still needs to be released for cellular utilization (i.e. ferritinprotein synthesis in the current cell assay) and there would be insufficient intracellular (lysosomal) acidification for this alone to drive the release and cytosolic iron transit. Skotland et al. [50] developed a simplified endosomal/lysosomal solution that included $10 \mathrm{mM}$ citrate and this chelator might, when aided by endosomal/lysosomal acidification, enable the breakdown and release of $\mathrm{Fe}$ from these fine, ligand-destabilized ferrihydritelike particles. We showed that under these simplified endosomal/lysosomal conditions soluble Fe could be released 
Figure 2. Ferritin-protein levels in Caco-2 cells following exposure to LM Fe(III) poly oxo-hydroxide (nano Fe), $\mathrm{Fe}$ (III) maltol (FeM) or Fe(II) sulphate-ascorbate (FeSO4 + AA).
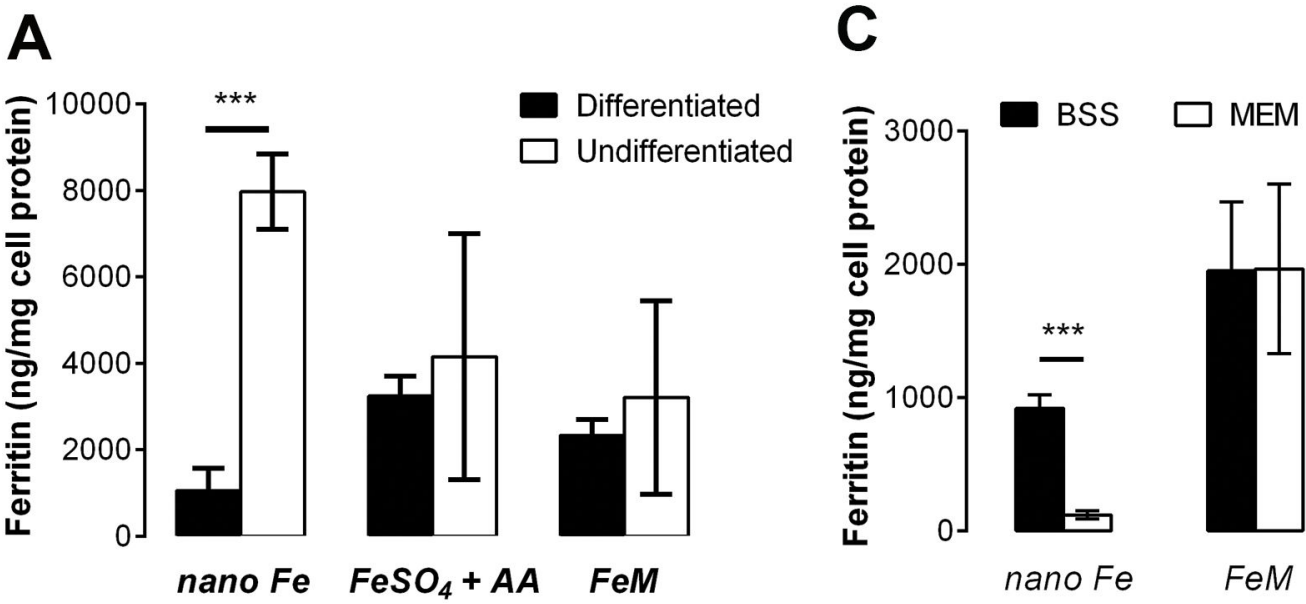

B
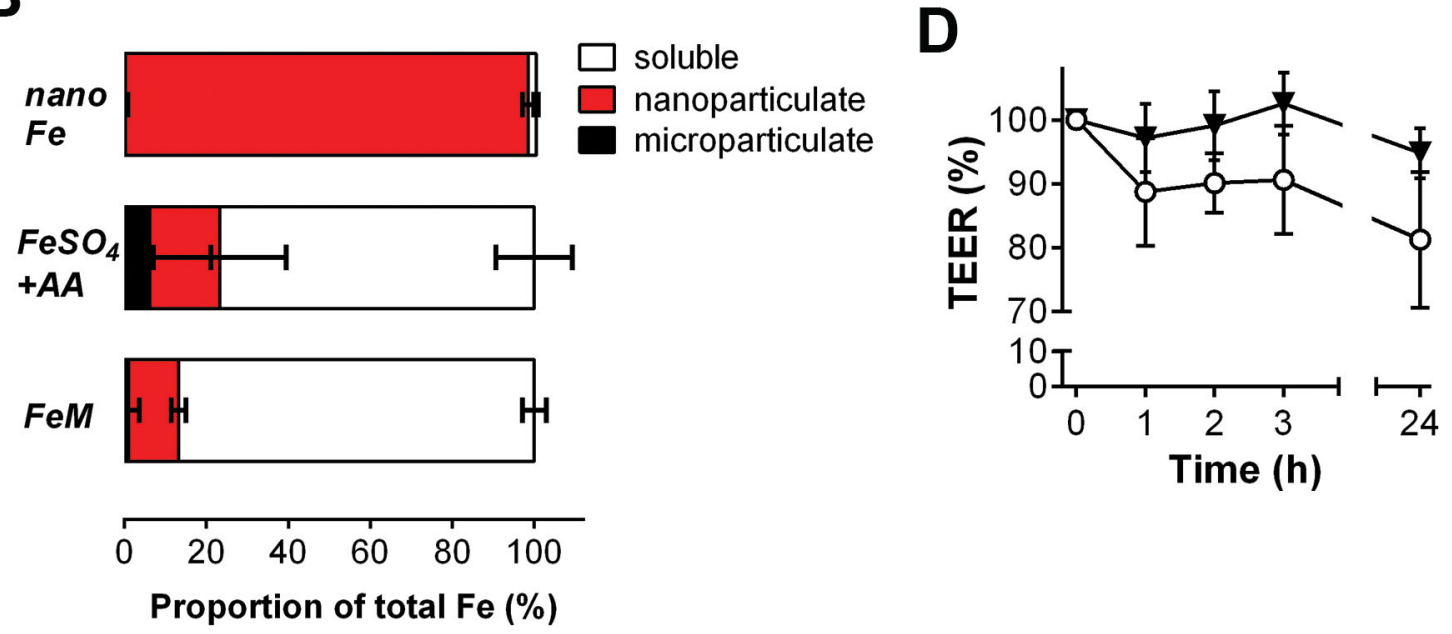

Figure 2. Ferritin-protein levels in Caco-2 cells following exposure to LM Fe(III) poly oxo-hydroxide (nano Fe), Fe(III) maltol $(\mathrm{FeM})$ or $\mathrm{Fe}(\mathrm{II})$ sulphate-ascorbate $\left(\mathrm{FeSO}_{4}+\mathrm{AA}\right)$. A, Ferritin-protein regulation in differentiated and undifferentiated cells. ${ }^{* * *}$, $p=0.0003$. Cells were incubated for $1 \mathrm{~h}$ with $200 \mu \mathrm{M}$ Fe plus a further $23 \mathrm{~h}$ in fresh, non-supplemented MEM to allow for ferritin formation. B, Phase distribution of $\mathrm{Fe}$ in the BSS uptake medium: i.e. fractional percentage of microparticulate (black bars), nanoparticulate (red bars) and soluble Fe (open bars) for each Fe material. Values are mean \pm s.d. of 3 independent experiments. C, Effect of LM Fe(III) poly oxo-hydroxide particle dispersion (in BSS medium, closed bars) or agglomeration (in MEM medium, open bars) on ferritin-protein levels in differentiated cells: the LM Fe(III) poly oxo-hydroxide was dispersed in its nano-form (99 $\pm 2 \%$ nano) using BSS or agglomerated (97 $\pm 2 \%$ microparticulate) using MEM. Data are mean of 3 independent experiments (each experiment with 3 replicate wells). FeM: soluble iron control, Fe(III) maltol. ${ }^{* * *}, p=0.0002$ for the comparison between BSS and MEM. D, TEER changes in differentiated Caco-2 cell monolayer at different time points during incubation with BSS supplemented with LM Fe(III) poly oxo-hydroxide (open circles) or non-supplemented BSS control (closed inverted triangles). Incubations were for $3 \mathrm{~h}$ with $200 \mu \mathrm{M} \mathrm{Fe}$ (measurements at 1, 2 \& $3 \mathrm{~h}$ ) plus a further $21 \mathrm{~h}$ in fresh, non-supplemented MEM (24-h). Values are expressed as a percentage of the initial measurement and are shown as mean \pm s.d. of 3 independent experiments (each experiment with 3 replicate wells). Experimental points are connected with a solid line to aid visualization and not because a linear relationship is assumed between time and TEER measurement. Detailed methodology is available in the Methods Section and in Methods S1. doi: $10.1371 /$ journal.pone.0081250.g002 
Figure 3. Cellular uptake of nanoparticulate LM Fe(III) poly oxo-hydroxide by Caco-2 cells.

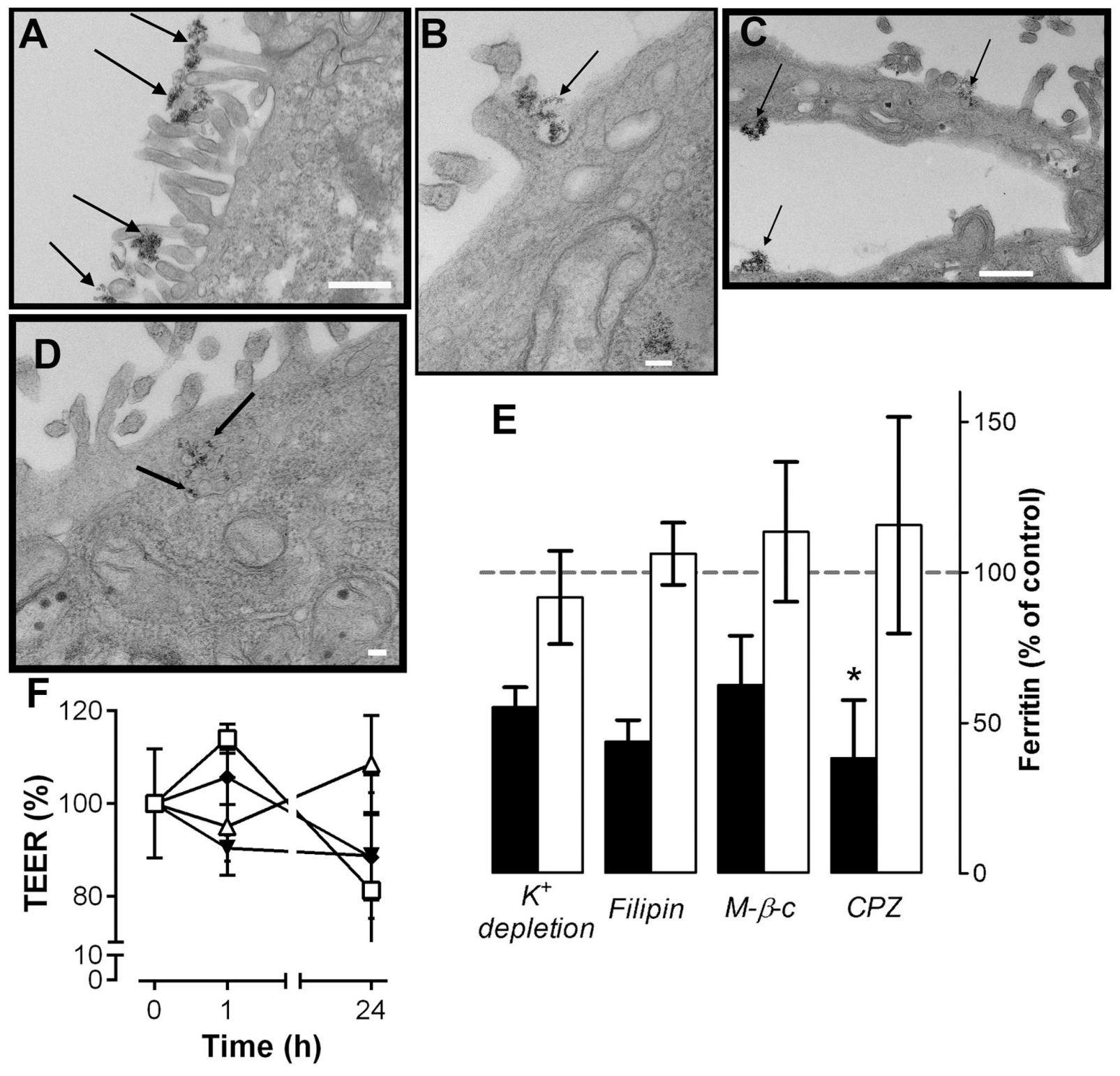

Figure 3. Cellular uptake of nanoparticulate LM Fe(III) poly oxo-hydroxide by Caco-2 cells. A, B, C, D TEM images showing differentiated Caco-2 cells incubated with LM Fe(III) poly oxo-hydroxide. A, arrows show particle clusters adhering to the cell membrane microvilli (scale bar, $500 \mathrm{~nm}$ ). B, arrows indicate invagination on the cell membrane (scale bar, $100 \mathrm{~nm}$ ). C and D, arrows indicate Fe accumulation inside the cell (scale bars: panel C, $500 \mathrm{~nm}$ and panel D, $100 \mathrm{~nm}$ ). E, Effect of chemical inhibitors of endocytosis-related pathways on Fe utilization by differentiated Caco-2 cells. Data are shown as a percentage of the controls (without inhibitor) after a $1 \mathrm{~h}$ exposure to LM Fe(III) poly oxo-hydroxide (black bars) or Fe(III) maltol (open bars) co-incubated with either chlorpromazine (CPZ), potassium-free BSS ( $\mathrm{K}^{+}$depletion), filipin or methyl- $\beta$-cyclodextrin (M- $\left.\beta-c\right)$, plus $23 \mathrm{~h}$ in fresh nonsupplemented MEM. Results are mean \pm s.d. of 3 independent experiments with 3 replicate wells per experiment for chlorpromazine $\left({ }^{*}, p=0.02\right.$ relative to control) or triplicate wells of the same experiment for the remaining inhibitors. $\mathbf{F}$, Change in TEER in the Caco-2 cell monolayer following a $1 \mathrm{~h}$ exposure to chlorpromazine (closed diamonds), $\mathrm{K}^{+}$-free BSS (open triangles), M- $\beta$-c (open squares) or non-supplemented BSS (closed inverted triangles) and with $23 \mathrm{~h}$ further incubation in fresh MEM (24 h total). Values are a percentage of the initial measurement $(0 \mathrm{~h})$ and are shown as mean \pm s.d. as above. Experimental points are connected with a solid line to aid visualization and not because a linear relationship is assumed between time and TEER measurement. Detailed methodology is available in the Methods Section and in Methods S1.

doi: 10.1371/journal.pone.0081250.g003 
within hours from the LM $\mathrm{Fe}(\mathrm{III})$ poly oxo-hydroxide (ferrihydrite) structures at $\mathrm{pH} 5.0$ (Figure 4A) whereas, in the absence of ligand modification, the native $\mathrm{Fe}(\mathrm{III})$ poly oxohydroxide was poorly broken down and little soluble $\mathrm{Fe}$ was released (Figure 4A). This 'destabilization' role of low molecular weight ligands in the nano-structured $\mathrm{Fe}$ (III) poly oxo-hydroxide indicates a more likely physiological role for them in the gut lumen rather than, as originally proposed [19], as donors of $\mathrm{Fe}$ (III) to mucin. Next, using cell studies and monensin to inhibit endosomal/lysosomal acidification [39], we showed a monensin-dose-dependent reduction (i.e. $\log _{10}$ [monensin] versus [ferritin-protein], $\left.\mathrm{r}^{2}=0.935, p<0.05\right)$ in $\mathrm{Fe}$ utilization by differentiated Caco-2 cells when exposed to LM Fe(III) poly oxo-hydroxide (Figure 4B), with statistically significant inhibition of ferritin formation at monensin doses $\geq 7.5 \mu \mathrm{M}(p=0.002)$. Again, soluble $\mathrm{Fe}$ was unaffected. The monensin doses used here were equivalent to those reported previously in inhibition studies of endosomal/lysosomal acidification in Caco-2 cells $[51,52]$ or other cell types $[53,54]$, even though by $24 \mathrm{~h}$ some disruption of the monolayer was visible by TEER measurements particularly at the highest monensin dose (Figure 4C). Nonetheless, the monolayer was intact during the 1 hour cell exposure to Fe (Figure 4C) and, when examined microscopically, the cell monolayers appeared integral and healthy at doses of monensin up to $10 \mu \mathrm{M}$ which still greatly inhibited ferritin-protein formation (Figure 4B), and there were similar protein levels in the presence and absence of the inhibitor (Figure S4).

Finally, we confirmed that none of the inhibitors caused significant agglomeration of the nanoparticles in the supplemented uptake medium (Table S1).

\section{Overall Discussion}

The Caco-2 cell line has been extensively used for iron uptake studies [55-59] as following confluence it differentiates into a polarised cell monolayer that exhibits a phenotype similar to human small intestinal enterocytes $[60,61]$.

Our data suggest that an endocytic, apical uptake mechanism exists in these differentiated Caco-2 cells for uptake of luminally hydrolysed (poly oxo-hydroxide) dietary $\mathrm{Fe}(\mathrm{III})$. This route apparently relies on endocytic uptake of small clusters of LM Fe(III) poly oxo-hydroxide nanoparticles which agglomerate at the cell membrane. Many cellular studies on nanoparticulate uptake and processing are challenged with issues of agglomeration and aggregation meaning that, finally, cells are exposed to micron-sized clusters which will be acquired and processed differently compared to genuinely disperse nanostructures $[46,62,63]$. Thus we paid considerable attention to developing a cell culture medium that mitigated against such pitfalls and retained appropriate dispersion of the particles prior to cell delivery [31]. The finding that these fine LM Fe(III) poly oxo-hydroxide nanoparticles then tend to agglomerate at the cell membrane must be interpreted with caution. It could be that the processing required to produce thin sections for electron microscopy induced clustering. However, small agglomerates of nanoparticles were observed in endosomal/lysosomal compartments within the cell and, so, the

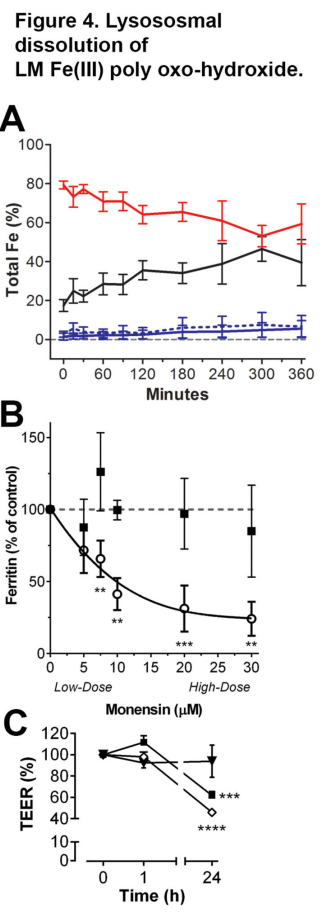

Figure 4. Lysososmal dissolution of LM Fe(III) poly oxohydroxide. A, Solubility in simulated lysosomal conditions at $\mathrm{pH} 5.0$ with $10 \mathrm{mM}$ citric acid and $0.15 \mathrm{M} \mathrm{NaCl}$. Soluble Fe was measured by ICP-OES following 5 min ultrafiltration (3000 Da MWCO) for the LM Fe(III) poly oxo-hydroxide (black) and for un-modified $\mathrm{Fe}(\mathrm{III})$ poly oxo-hydroxide (solid blue). Nanoparticulate $\mathrm{Fe}$ was obtained from the $\mathrm{Fe}$ in the supernatant following centrifugation excluding the soluble (ultrafilterable) $\mathrm{Fe}$, and is shown for LM Fe(III) poly oxohydroxide (red) and for un-modified $\mathrm{Fe}(\mathrm{III})$ poly oxo-hydroxide (dotted blue). Values are plotted as mean \pm s.d. of 3 independent experiments (each experiment with 3 replicates). B, Effect of inhibition of lysosomal acidification using monensin on Fe utilization by differentiated Caco-2 cells. Data are shown as a percentage of the control (without monensin) at $24 \mathrm{~h}$ : i.e. 1 $\mathrm{h}$ exposure to $200 \mu \mathrm{M}$ nanoparticulate LM Fe(III) poly oxohydroxide (open circles) or $\mathrm{Fe}$ (III) maltol (closed squares) \pm 5-30 $\mu \mathrm{M}$ monensin followed by $23 \mathrm{~h}$ in non-supplemented MEM. Results are means \pm s.d. of 3 independent experiments (each experiment with 3 replicate wells). ${ }^{* *}, p<0.005$; ***, $p<0.001$ in relation to the soluble Fe control (Fe(III)maltol). C, Change in TEER in the Caco-2 cell monolayer following $1 \mathrm{~h}$ exposure to $10 \mu \mathrm{M}$ monensin (closed squares), $30 \mu \mathrm{M}$ monensin (open diamonds) or non-supplemented BSS control (closed inverted triangles) and with $23 \mathrm{~h}$ further incubation in fresh MEM (24 $\mathrm{h}$ in total). Values are expressed as a percentage of the initial measurement at the start of the exposure time (corresponding to $0 \mathrm{~h}$ ) and are shown as mean \pm s.d. of 2 independent experiments (each experiment with 3 replicate wells). Experimental points are connected with a solid line to aid visualization and not because a linear relationship is assumed between time and TEER measurement. ***, $p=0.0003 ;{ }^{* * * *}, p<0.0001$ in relation to the non-supplemented BSS control.

doi: 10.1371/journal.pone.0081250.g004 
particles must have been taken up either as individual particles or clusters. Moreover, and importantly, we observed loose clusters almost always smaller than $200 \mathrm{~nm}$ diameter and it is at around this size that uptake mechanisms may switch between classical endocytosis and macropinocytosis [46,64]. There appears to be no mechanism of macropinocytosis in intestinal enterocytes, including differentiated Caco- 2 cells, and phagocytosis has been rarely demonstrated [65,66]. The inhibitors used here were classical endocytic inhibitors and our findings suggest endocytosis of individual particles or membrane-induced small clusters. We accept that the specificity of $\mathrm{K}^{+}$-depletion to clathrin-mediated endocytosis and methyl- $\beta$-cyclodextrin to caveolin-dependent endocytosis in HuTu cells has been previously questioned [34]. However, chlorpromazine has been consistently shown to be highly specific for clathrin-mediated endocytosis in both HuTu and Caco-2 cells, providing comparable inhibition rates to siRNA approaches [34,67]. Filipin also appears specific to caveolindependent endocytosis [35,68]. Nonetheless, we do not, here, suggest dominance of one specific form of endocytosis for the uptake of LM Fe(III) poly oxo-hydroxide nanoparticles as further work may be required to conclude on this.

Our observations on Fe utilization by Caco-2 cells, through endocytic uptake and lysosomal dissolution of nanoparticulate LM Fe(III) poly oxo-hydroxide, are still consistent with the established fact that DMT-1 is indispensable for mammalian Fe absorption and, therefore, survival [69]. DMT-1, as well as being the enterocyte $\mathrm{Fe}(\mathrm{II})$ apical transporter is probably also the export transporter of the lysosomal membrane [70-72]: i.e. the point from where endocytosed and then solubilized nanoparticulate $\mathrm{Fe}$ would join the common $\mathrm{Fe}$ pool. The elegant study of Gunshin et al. [69], utilizing an intestinalspecific DMT-1 knock-out model termed Slc11a2 intlint (which is a cross of Slc11a2flox/flox mice with mice carrying a Villin-Cre transgene), proved essentiality of this transporter for intestinal non-haem iron absorption after birth [69]. However, the Slc11a2 intint model has DMT1 knocked-out in the entire enterocyte and not solely from the apical membrane [69] and, therefore, this study did not eliminate DMT-1 functionality in both apical uptake and cytosolic processing of intracellular iron.A further point is that laboratory rodent diets poorly represent the human diet. Invariably the laboratory diet is rich in fibrous carbohydrate that is poorly digestible in the upper gastrointestinal tract and will bind $\mathrm{Fe}(\mathrm{III})$ thereby preventing mucosal access. Thus, $\mathrm{Fe}(\mathrm{II})$ sulphate is commonly supplemented into rodent laboratory chow, as for example in the RMH 3000 LabDiet (PMI Nutrition International) used by Gunshin et al. in the study referred to above [69]. In this case, the essentiality of an $\mathrm{Fe}(\mathrm{II})$ transporter would be favoured.

Future in vivo rodent experiments could use a diet representing the more varied human diet for non-heme $\mathrm{Fe}$ (e.g., mixed $\mathrm{Fe}(\mathrm{II})-\mathrm{Fe}(\mathrm{III})$ salts that undergo gastric dissolution, plus ferritin-protein) and then establish, in the Slc11a2 intint mouse, whether or not there is enterocyte lysosomal accumulation of $\mathrm{Fe}$ (i.e. initial apical uptake due to a non DMT-1 pathway for the hydrolysed $\mathrm{Fe}(\mathrm{III})$ and possibly ferritinprotein fractions, but accumulation due to export failure with lack of lysosomal DMT-1). Such a diet fed to Slc11a2 $2^{\text {intint }}$ mice will delineate the essential role of DMT-1 for apical iron uptake versus lysosomal iron efflux. Indeed, Kalgaonkar and Lonnerdal [3] have speculated that dietary ferritin $\mathrm{Fe}$, which contains subunits of ferrihydrite similar in structure to the LM $\mathrm{Fe}$ (III) poly oxo-hydroxide nanoparticles used herein [73], may not all be dissolved under post-prandial gastric conditions, and could be absorbed whole by duodenal enterocytes and subsequently broken down intra-lysosomally. Moreover, elsewhere in mammalian Fe physiology, the lysosome is a safe reservoir for catabolism of Fe-rich species, whether it be ferritin-protein, red blood cells or transferrin turnover $[71,74]$. Free $\mathrm{Fe}$ is potentially redox active and thus toxic to cells. So the concept that cells lining the gut are protected from redox damage (Fe(III) $\leftrightarrow \mathrm{Fe}(\mathrm{II})+\mathrm{e}^{-}$) due to luminal nanoparticulate LM Fe(III) poly oxo-hydroxide formation, which is only available for breakdown in the safest compartment of the cell, i.e. the endosome/lysosome, is consistent with other aspects of $\mathrm{Fe}$ metabolism. Finally, of particular note, is a paper by Theil and colleagues [75], published during preparation of this manuscript, where they show that the Fe derived from dietary ferritin-protein (i.e. protein-encapsulated ferrihydrite-like nanostructures) is absorbed differently in rats and humans to that of DMT-1-dependent Fe(II). Moreover, their findings invoke an epithelial endocytic process, which we believe we detail here: i.e. the fraction of dietary iron derived from ferritin-protein ingestion could lose its protein shell but maintain its ferrihydritelike structure following gastrointestinal digestion and 'ride' the endocytic mechanisms that exists for endogenously formed LM $\mathrm{Fe}$ (III) poly oxo-hydroxide. Ultimately, the two forms may look very similar, being 2-5 nm diameter, destabilized ferrihydrite [73] and thus, readily solubilized by the enterocyte endosome/ lysosome.

Our preliminary data in duodenal epithelial cells (HuTu-80 cell line) using siRNA targeting DMT1 further supports a pathway independent of DMT1 and Dcyt B for the intestinal uptake of LM Fe(III) poly oxo-hydroxide and, thus, not involving reduction of $\mathrm{Fe}(\mathrm{III})$ to $\mathrm{Fe}(\mathrm{II})$ (Figure S5).

We have demonstrated the existence of a nanoparticulate ferrihydrite-like phase in a model of luminally hydrolysed $\mathrm{Fe}$ (III) and, using a synthetic nanoparticulate ligand-modified ferrihydrite as an analogue, we have shown the existence of an endocytic pathway of $\mathrm{Fe}$ uptake by Caco- 2 cells, a gut epithelial cell model, followed by lysosomal dissolution of nanoparticulate LM Fe(III) poly oxo-hydroxide which is consistent with in vivo observations elsewhere [75].

These in vitro mechanistic findings now need to be replicated by in vivo data for physiological relevance, and, it is noteworthy that, when supplemented into the diet of iron deficient rats, these LM Fe(III) poly oxo-hydroxide structures improved haemoglobin levels in line with $\mathrm{Fe}$ (II) sulphate supplementation [Pereira, Latunde-Dada and Powell unpublished observations].

\section{Supporting Information}

\section{Methods S1. (DOCX)}

Table S1. Iron solid-phase distribution of $200 \mu \mathrm{M}$ Fe as LM $\mathrm{Fe}$ (III) poly oxo-hydroxide (nano $\mathrm{Fe}$ ) and $\mathrm{Fe}$ (III) maltol 
(FeM) co-incubated with different chemical inhibitors in the BSS uptake medium.

(DOCX)

Figure S1. Caco-2 cell growth and differentiation parameters in monolayers grown for $\mathbf{2 1}$ days. A, cell protein (open circles) and transepithelial electrical resistance (TEER, closed squares). Data shown are mean \pm s.d. of $n=3$ independent experiments (each experiment with 12 replicate wells). B, alkaline phosphatase activity (closed triangles). Data shown are mean \pm s.d. of $n=3$ independent experiments (each experiment with 3 replicate wells). Under these culture conditions the cell monolayer is fully confluent at day 5 postseeding and differentiated at day 10 post-seeding in accordance with reference values reported in the literature $[76,77]$.

Figure S2. Effect of low temperature incubation on ferritinprotein levels in Caco-2 cells following exposure to LM $\mathrm{Fe}$ (III) poly oxo-hydroxide (nano $\mathrm{Fe}$ ) or $\mathrm{Fe}$ (III) maltol (FeM). Cells were incubated for $1 \mathrm{~h}$ in BSS at $37^{\circ} \mathrm{C}$ (closed bars) or $4^{\circ} \mathrm{C}$ (open bars) supplemented with $200 \mu \mathrm{M}$ Fe plus a further $23 \mathrm{~h}$ in fresh, non-supplemented MEM to allow for ferritin formation. Data are mean ( \pm s.d.) of 3 replicate wells within one experiment. ${ }^{* *}, p=0.001$.

(TIF)

Figure S3. TEM image showing differentiated Caco-2 cells incubated at $37^{\circ} \mathrm{C}$ for $3 \mathrm{~h}$ with (A) non-supplemented control media (i.e. balanced salt solution, BSS), (B) control BSS supplemented with maltol alone and (C) BSS supplemented with $500 \mu \mathrm{M}$ Fe as the soluble $\mathrm{Fe}$ (III) maltol chelate. Scale bar, $500 \mathrm{~nm}$.

(TIF)

Figure S4. Effect of monensin on cellular protein levels in Caco-2 monolayers. Cells were incubated for $1 \mathrm{~h}$ in BSS supplemented with different concentrations of monensin plus a further $23 \mathrm{~h}$ in fresh, non-supplemented MEM. Box and whisker plots show median, minimum and maximum for $n=6$ independent experiments. The red solid line represents the

\section{References}

1. Theil EC (2004) Iron, ferritin, and nutrition. Annu Rev Nutr 24: 327-343. doi:10.1146/annurev.nutr.24.012003.132212. PubMed: 15189124

2. Sharp PA (2010) Intestinal iron absorption: regulation by dietary \& systemic factors. Int J Vitam Nutr Res 80: 231-242. doi: 10.1024/0300-9831/a000029. PubMed: 21462105

3. Kalgaonkar S, Lönnerdal B (2009) Receptor-mediated uptake of ferritinbound iron by human intestinal Caco-2 cells. J Nutr Biochem 20: 304-311. doi:10.1016/j.jnutbio.2008.04.003. PubMed: 18602806.

4. Simpson RJ, Peters TJ (1990) Forms of soluble iron in mouse stomach and duodenal lumen: significance for mucosal uptake. $\mathrm{Br} \mathrm{J}$ Nutr 63: 79-89. doi:10.1079/BJN19900093. PubMed: 2317479.

5. Dorey C, Cooper C, Dickson DP, Gibson JF, Simpson RJ et al. (1993) Iron speciation at physiological $\mathrm{pH}$ in media containing ascorbate and oxygen. Br J Nutr 70: 157-169. doi:10.1079/BJN19930113. PubMed: 8399098.

6. Hoppler M, Schönbächler A, Meile L, Hurrell RF, Walczyk T (2008) Ferritin-iron is released during boiling and in vitro gastric digestion. $J$ Nutr 138: 878-884. PubMed: 18424595. mean cellular protein for all experiments and the dotted red lines represent the corresponding 95\% confidence interval. No statistical differences were found for any monensin concentration in relation to control cells incubated without monensin $(0 \mu \mathrm{M})$.

(TIF)

Figure S5. Effect of siRNA targeting of DMT1 (closed bars) and Dcyt B (open bars) on iron uptake in HuTu cells. HuTu cells were transfected with siRNAs and, after 3 days, the cells were incubated for $1 \mathrm{~h}$ in BSS supplemented with $10 \mu \mathrm{M}$ Fe as soluble $\mathrm{Fe}(\mathrm{II})$ (ferrous sulphate) or LM $\mathrm{Fe}$ (III) poly oxohydroxide (nano $\mathrm{Fe}$ ) plus a further $23 \mathrm{~h}$ in fresh, nonsupplemented MEM to allow for ferritin formation. Pattern bars indicate scrambled-transfected cells. Data are mean $( \pm$ s.d.) of 3 replicate wells within one experiment. ${ }^{* * *}, p<0.0001$. (TIF)

\section{Acknowledgements}

This work is a publication of the UK Medical Research Council (U105960399). B.I.M thanks the MRC and Rank Prize Funds for her PhD studentship. We thank Emma Thomas-McKay for kindly collecting the TEM images of the cells and Ewgenia Roth for kindly collecting some of the TEER measurements. We acknowledge $\operatorname{Dr} G$ Latunde-Dada for her guidance and expertise with the cell transfection and siRNA experiments. A.P.B. holds an Engineering and Physical Science Research Council (UK) Advanced Research fellowship (EP/E059678/1).

\section{Author Contributions}

Conceived and designed the experiments: DIAP BIM JJP. Performed the experiments: DIAP BIM LKP LP MFA. Analyzed the data: DIAP BIM MFA APB. Contributed reagents/materials/ analysis tools: BL NF SFAB APB. Wrote the manuscript: DIAP APB JJP. Developed the hypothesis behind this research: JJP DIAP. Provided input on development of the hypothesis behind this research: SFAB NF APB. Had primary responsibility for final content: DIAP JJP. Read, provided input to and approved the manuscript: DIAP BIM NF SFAB MFA LKP LP BL APB JJP.

7. Latunde-Dada GO, Neale RJ (1986) Availability of iron from foodsreview. Food Technology 21: 255-268.

8. Carpenter CE, Ummadi M (1995) Iron Status Alters the Adsorption, Uptake, and Absorption Capacities of Rat Duodenum for Ferrous and Ferric Iron. Nutrition Research 15: 1129-1138. doi: 10.1016/0271-5317(95)00072-Q.

9. Anderson GJ, Frazer DM, McKie AT, Vulpe CD, Smith A (2005) Mechanisms of haem and non-haem iron absorption: lessons from inherited disorders of iron metabolism. Biometals 18: 339-348. doi: 10.1007/s10534-005-3708-8. PubMed: 16158226.

10. McKie AT, Barrow D, Latunde-Dada GO, Rolfs A, Sager G et al. (2001) An iron-regulated ferric reductase associated with the absorption of dietary iron. Science 291: 1755-1759. doi:10.1126/science.1057206. PubMed: 11230685.

11. Mackenzie B, Garrick MD (2005) Iron Imports. II. Iron uptake at the apical membrane in the intestine. Am J Physiol Gastrointest Liver Physiol 289: G981-G986. doi:10.1152/ajpgi.00363.2005. PubMed: 16286504. 
12. Gunshin H, Mackenzie B, Berger UV, Gunshin Y, Romero MF et al. (1997) Cloning and characterization of a mammalian proton-coupled metal-ion transporter. Nature 388: 482-488. doi:10.1038/41343. PubMed: 9242408.

13. McKie AT (2008) The role of Dcytb in iron metabolism: an update. Biochem Soc Trans 36: 1239-1241. doi:10.1042/BST0361239. PubMed: 19021532.

14. Flynn CM (1984) Hydrolysis of Inorganic Iron(III) Salts. Chem Rev 84 31-41. doi:10.1021/cr00059a003.

15. Powell JJ, Whitehead MW, Ainley CC, Kendall MD, Nicholson JK et al. (1999) Dietary minerals in the gastrointestinal tract: hydroxypolymerisation of aluminium is regulated by luminal mucins. $J$ Inorg Biochem 75: 167-180. doi:10.1016/S0162-0134(99)00094-X. PubMed: 10474202

16. Conrad ME, Umbreit JN, Moore EG (1991) A role for mucin in the absorption of inorganic iron and other metal cations. A study in rats. Gastroenterology 100: 129-136. PubMed: 1983814.

17. Berner LA, Miller DD, Van Campen D (1986) Absorption of iron from ferric hydroxide polymers introduced into ligated rat duodenal segments. J Nutr 116: 259-264. PubMed: 3944661

18. Simovich M, Hainsworth LN, Fields PA, Umbreit JN, Conrad ME (2003) Localization of the iron transport proteins Mobilferrin and DMT-1 in the duodenum: the surprising role of mucin. Am J Hematol 74: 32-45. doi: 10.1002/ajh.10383. PubMed: 12949888

19. Powell JJ, Jugdaohsingh R, Thompson RP (1999) The regulation of mineral absorption in the gastrointestinal tract. Proc Nutr Soc 58: 147-153. doi:10.1079/PNS19990020. PubMed: 10343352.

20. Webb J, Multani JS, Saltman P, Gray HB (1973) Spectroscopic and magnetic studies of iron(3) gastroferrin. Biochemistry 12: 265-267. doi: 10.1021/bi00726a014. PubMed: 4683000

21. Multani JS, Cepurneek CP, Davis PS, Saltman P (1970) Biochemical characterization of gastroferrin. Biochemistry 9: 3970-3976. doi: 10.1021/bi00822a015. PubMed: 5501652.

22. Davis PS, Multani JS, Cepurneek CP, Saltman P (1969) Isolation of gastroferrin from human gastric juice. Biochem Biophys Res Commun 37: 532-537. doi:10.1016/0006-291X(69)90948-6. PubMed: 5356534

23. Deller DJ, Edwards RG, Dart G, Luke CG, Davis PS (1969) Gastric iron binding substance (gastroferrin) in a family with haemochromatosis. Australas Ann Med 18: 36-42. PubMed: 5776898.

24. Luke CG, Davis PS, Deller DJ (1967) Change in gastric iron-binding protein (gastroferrin) during iron-deficiency anaemia. Lancet 1: 926-927. PubMed: 4164401

25. Dressman JB, Berardi RR, Dermentzoglou LC, Russell TL, Schmaltz SP et al. (1990) Upper gastrointestinal (GI) pH in young, healthy men and women. Pharm Res 7: 756-761. doi:10.1023/A:1015827908309. PubMed: 2395805

26. Rudzki Z, Baker RJ, Deller DJ (1973) The iron-binding glycoprotein of human gastric juice. II. Nature of the interaction of the glycoprotein with iron. Digestion 8: 53-67. doi:10.1159/000197300. PubMed: 4776489.

27. Jambor JL, Dutrizac JE (1998) Occurrence and Constitution of Natural and Synthetic Ferrihydrite, a Widespread Iron Oxyhydroxide. Chem Rev 98: 2549-2586. doi:10.1021/cr970105t. PubMed: 11848971.

28. Cornell RL, Schwertmann U (2003) The iron oxides: structure, preparation, reactions, occurrences and uses Weinham. Wiley-VCH.

29. Rudzki Z, Deller DJ (1973) The iron-binding glycoprotein of human gastric juice. I. Isolation and characterization. Digestion 8: 35-52. doi: 10.1159/000197299. PubMed: 4776488.

30. Powell J, Bruggraber S, Faria N, Pereira D (2008) Ligand modified poly oxo-hydroxy metal ion materials, their uses and processes for their preparation. In: Organization WIP, editor. U.K.

31. Mergler BI (2012) Enterocyte uptake of nanoparticulate iron(III) oxohydroxide [PhD Thesis]. U.K.: University of Cambridge.

32. Vanden Broeck D, De Wolf MJ (2006) Selective blocking of clathrinmediated endocytosis by RNA interference: epsin as target protein. BioTechniques 41: 475-484. doi:10.2144/000112265. PubMed: 17068964.

33. Ivanov Al (2008) Pharmacological inhibition of endocytic pathways: is it specific enough to be useful? Methods Mol Biol 440: 15-33. doi: 10.1007/978-1-59745-178-9_2. PubMed: 18369934.

34. Vercauteren D, Vandenbroucke RE, Jones AT, Rejman J, Demeester J et al. (2010) The use of inhibitors to study endocytic pathways of gene carriers: optimization and pitfalls. Mol Ther 18: 561-569. doi: 10.1038/mt.2009.281. PubMed: 20010917

35. San Martin CD, Garri C, Pizarro F, Walter T, Theil EC et al. (2008) Caco-2 intestinal epithelial cells absorb soybean ferritin by mu2 (AP2)dependent endocytosis. J Nutr 138: 659-666. PubMed: 18356317.

36. Gratton SE, Ropp PA, Pohlhaus PD, Luft JC, Madden VJ et al. (2008) The effect of particle design on cellular internalization pathways. Proc
Natl Acad Sci U S A 105: 11613-11618. doi:10.1073/pnas.0801763105. PubMed: 18697944

37. Conte MP, Petrone G, Longhi C, Valenti P, Morelli R et al. (1996) The effects of inhibitors of vacuolar acidification on the release of Listeria monocytogenes from phagosomes of Caco-2 cells. J Med Microbiol 44: 418-424. doi:10.1099/00222615-44-6-418. PubMed: 8636958.

38. Pohlmann R, Krüger S, Hasilik A, von Figura K (1984) Effect of monensin on intracellular transport and receptor-mediated endocytosis of lysosomal enzymes. Biochem J 217: 649-658. PubMed: 6231917.

39. Mollenhauer HH, Morré DJ, Rowe LD (1990) Alteration of intracellular traffic by monensin; mechanism, specificity and relationship to toxicity. Biochim Biophys Acta 1031: 225-246. doi: 10.1016/0304-4157(90)90008-Z. PubMed: 2160275

40. Janney DE, Cowley JM, Buseck PR (2000) Structure of synthetic 2-line ferrihydrite by electron nanodiffraction. American Mineralogist 85 : 1180-1187.

41. Pan YH, Vaughan G, Brydson R, Bleloch A, Gass M et al. (2010) Electron-beam-induced reduction of $\mathrm{Fe}(3+)$ in iron phosphate dihydrate, ferrihydrite, haemosiderin and ferritin as revealed by electron energy-loss spectroscopy. Ultramicroscopy 110: 1020-1032. doi: 10.1016/j.ultramic.2010.01.008.

42. Harvey RS, Reffitt DM, Doig LA, Meenan J, Ellis RD et al. (1998) Ferric trimaltol corrects iron deficiency anaemia in patients intolerant of iron. Aliment Pharmacol Ther 12: 845-848. doi:10.1046/j. 1365-2036.1998.00380.x. PubMed: 9768526

43. Kemp SJ, Thorley AJ, Gorelik J, Seckl MJ, O'Hare MJ et al. (2008) Immortalization of human alveolar epithelial cells to investigate nanoparticle uptake. Am J Respir Cell Mol Biol 39: 591-597. doi: 10.1165/rcmb.2007-0334OC. PubMed: 18539954

44. Smith PJ, Giroud M, Wiggins HL, Gower F, Thorley JA et al. (2012) Cellular entry of nanoparticles via serum sensitive clathrin-mediated endocytosis, and plasma membrane permeabilization. Int $\mathrm{J}$ Nanomedicine 7: 2045-2055. PubMed: 22619541.

45. Guignot J, Bernet-Camard MF, Poüs C, Plançon L, Le Bouguenec C et al. (2001) Polarized entry of uropathogenic Afa/Dr diffusely adhering Escherichia coli strain IH11128 into human epithelial cells: evidence for alpha5beta1 integrin recognition and subsequent internalization through a pathway involving caveolae and dynamic unstable microtubules. Infect Immun 69: 1856-1868. doi:10.1128/IAI. 69.3.1856-1868.2001. PubMed: 11179364.

46. Rejman J, Oberle V, Zuhorn IS, Hoekstra D (2004) Size-dependent internalization of particles via the pathways of clathrin- and caveolaemediated endocytosis. Biochem J 377: 159-169. doi:10.1042/ BJ20031253. PubMed: 14505488.

47. Yang H, Wang Y, Lai S, An H, Li Y et al. (2007) Application of atomic force microscopy as a nanotechnology tool in food science. J Food Sci 72: R65-R75. doi:10.1111/j.1750-3841.2006.00218.x. PubMed: 17995783.

48. Zhang SL, Li J, Lykotrafitis G, Bao G, Suresh S (2009) Size-Dependent Endocytosis of Nanoparticles. Advanced Materials 21: 419-424. doi: 10.1002/adma.200801393. PubMed: 19606281.

49. Oh JM, Choi SJ, Lee GE, Kim JE, Choy JH (2009) Inorganic Metal Hydroxide Nanoparticles for Targeted Cellular Uptake Through Clathrin-Mediated Endocytosis. Chem Asian J 4: 67-73. doi:10.1002/ asia.200800290. PubMed: 18988236.

50. Skotland T, Sontum PC, Oulie I (2002) In vitro stability analyses as a model for metabolism of ferromagnetic particles (Clariscan), a contrast agent for magnetic resonance imaging. J Pharm Biomed Anal 28: 323-329. doi:10.1016/S0731-7085(01)00592-1. PubMed: 11929675.

51. Anwar K, Kayden HJ, Hussain MM (2006) Transport of vitamin E by differentiated Caco-2 cells. J Lipid Res 47: 1261-1273. doi:10.1194/ jlr.M500523-JLR200. PubMed: 16569910.

52. Field FJ, Born E, Murthy S, Mathur SN (1998) Transport of cholesterol from the endoplasmic reticulum to the plasma membrane is constitutive in CaCo-2 cells and differs from the transport of plasma membrane cholesterol to the endoplasmic reticulum. J Lipid Res 39: 333-343. PubMed: 9507994.

53. Saermark T, Gratzl $M$ (1986) $\mathrm{Na}+/ \mathrm{Ca} 2+$ exchange in coated microvesicles. Biochem J 233: 643-648. PubMed: 2939825.

54. Subramanian VS, Marchant JS, Boulware MJ, Ma TY, Said HM (2009) Membrane targeting and intracellular trafficking of the human sodiumdependent multivitamin transporter in polarized epithelial cells. Am J Physiol Cell Physiol 296: C663-C671. doi:10.1152/ajpcell.00396.2008. PubMed: 19211916

55. Garcia MN, Flowers C, Cook JD (1996) The Caco-2 cell culture system can be used as a model to study food iron availability. J Nutr 126: 251-258. PubMed: 8558308 
56. Glahn RP, Jin F, Rutzke M, Welch RM (2006) Iron bioavailability from ferritin as measured via an in vitro digestion/Caco-2 cell culture model. FASEB Journal 20: A130-A131.

57. Glahn RP, Lee OA, Yeung A, Goldman MI, Miller DD (1998) Caco-2 cell ferritin formation predicts nonradiolabeled food iron availability in an in vitro digestion/Caco-2 cell culture model. J Nutr 128: 1555-1561. PubMed: 9732319.

58. Glahn RP, Wien EM, Van Campen DR, Miller DD (1996) Caco-2 cell iron uptake from meat and casein digests parallels in vivo studies: use of a novel in vitro method for rapid estimation of iron bioavailability. $J$ Nutr 126: 332-339. PubMed: 8558319.

59. Kalgaonkar S, Lönnerdal B (2008) Effects of dietary factors on iron uptake from ferritin by Caco-2 cells. J Nutr Biochem 19: 33-39. doi: 10.1016/j.jnutbio.2007.02.001. PubMed: 17509858

60. Alvarez-Hernandez X, Nichols GM, Glass J (1991) Caco-2 cell line: a system for studying intestinal iron transport across epithelial cell monolayers. Biochim Biophys Acta 1070: 205-208. doi: 10.1016/0005-2736(91)90165-5. PubMed: 1751528.

61. Artursson P (1990) Epithelial transport of drugs in cell culture. I: A model for studying the passive diffusion of drugs over intestinal absorptive (Caco-2) cells. J Pharm Sci 79: 476-482. doi:10.1002/jps. 2600790604. PubMed: 1975619

62. Wang SH, Lee CW, Chiou A, Wei PK (2010) Size-dependent endocytosis of gold nanoparticles studied by three-dimensional mapping of plasmonic scattering images. J Nanobiotechnology 8: 33. doi:10.1186/1477-3155-8-33. PubMed: 21167077.

63. Awaad A, Nakamura M, Ishimura K (2011) Imaging of size-dependent uptake and identification of novel pathways in mouse Peyer's patches using fluorescent organosilica particles. Nanomedicine.

64. Conner SD, Schmid SL (2003) Regulated portals of entry into the cell. Nature 422: 37-44. doi:10.1038/nature01451. PubMed: 12621426.

65. Leitch GJ, Ward TL, Shaw AP, Newman G (2005) Apical spore phagocytosis is not a significant route of infection of differentiated enterocytes by Encephalitozoon intestinalis. Infect Immun 73: 7697-7704. doi:10.1128/IAI.73.11.7697-7704.2005. PubMed: 16239574.

66. Yamauchi KE, Snel J (2000) Transmission electron microscopic demonstration of phagocytosis and intracellular processing of segmented filamentous bacteria by intestinal epithelial cells of the chick ileum. Infect Immun 68: 6496-6504. doi:10.1128/IAI. 68.11.6496-6504.2000. PubMed: 11035767.

67. Vanden Broeck D, De Wolf MJ (2006) Selective blocking of clathrinmediated endocytosis by RNA interference: epsin as target protein.
BioTechniques 41: 475-484. doi:10.2144/000112265. PubMed: 17068964.

68. Rothberg KG, Heuser JE, Donzell WC, Ying YS, Glenney JR et al (1992) Caveolin, a protein component of caveolae membrane coats. Cell 68: 673-682. doi:10.1016/0092-8674(92)90143-Z. PubMed: 1739974.

69. Gunshin H, Fujiwara Y, Custodio AO, Direnzo C, Robine S et al. (2005) Slc11a2 is required for intestinal iron absorption and erythropoiesis but dispensable in placenta and liver. J Clin Invest 115: 1258-1266. doi: 10.1172/JCI24356. PubMed: 15849611

70. Abouhamed M, Gburek J, Liu W, Torchalski B, Wilhelm A et al. (2006) Divalent metal transporter 1 in the kidney proximal tubule is expressed in late endosomes/lysosomal membranes: implications for renal handling of protein-metal complexes. Am J Physiol Renal Physiol 290: F1525-F1533. doi:10.1152/ajprenal.00359.2005. PubMed: 16449358.

71. Andrews NC (2000) Iron homeostasis: insights from genetics and animal models. Nat Rev Genet 1: 208-217. doi:10.1038/35043032. PubMed: 11252750 .

72. Tabuchi M, Yoshimori T, Yamaguchi K, Yoshida T, Kishi F (2000) Human NRAMP2/DMT1, which mediates iron transport across endosomal membranes, is localized to late endosomes and lysosomes in HEp-2 cells. J Biol Chem 275: 22220-22228. doi:10.1074/ jbc.M001478200. PubMed: 10751401

73. Pan YH, Sader K, Powell JJ, Bleloch A, Gass M et al. (2009) 3D morphology of the human hepatic ferritin mineral core: new evidence for a subunit structure revealed by single particle analysis of HAADFSTEM images. J Struct Biol 166: 22-31. doi:10.1016/j.jsb.2008.12.001. PubMed: 19116170.

74. Zhang Y, Mikhael M, Xu D, Li Y, Soe-Lin S et al. (2010) Lysosomal proteolysis is the primary degradation pathway for cytosolic ferritin and cytosolic ferritin degradation is necessary for iron exit. Antioxid Redox Signal 13: 999-1009. doi:10.1089/ars.2010.3129. PubMed: 20406137.

75. Theil EC, Chen H, Miranda C, Janser H, Elsenhans B et al. (2012) Absorption of iron from ferritin is independent of heme iron and ferrous salts in women and rat intestinal segments. J Nutr 142: 478-483. doi: 10.3945/jn.111.145854. PubMed: 22259191.

76. Ekmekcioglu C, Marktl W (1998) The effect of differentiation on the brush border membrane ferric reductase activity in Caco-2 cells. In Vitro Cell Dev Biol Anim 34: 674-676. doi:10.1007/s11626-998-0061-6. PubMed: 9794217.

77. Bravo SA, Nielsen CU, Amstrup J, Frokjaer S, Brodin B (2004) In-depth evaluation of Gly-Sar transport parameters as a function of culture time in the Caco-2 cell model. Eur J Pharm Sci 21: 77-86. doi:10.1016/ S0928-0987(03)00205-7. PubMed: 14706814 